\title{
Ganoderma tsugae Induces S Phase Arrest and Apoptosis in Doxorubicin-Resistant Lung Adenocarcinoma H23/0.3 Cells via Modulation of the PI3K/Akt Signaling Pathway
}

\author{
Yang-Hao Yu, ${ }^{1,2}$ Han-Peng Kuo, ${ }^{3}$ Hui-Hsia Hsieh, ${ }^{4}$ Jhy-Wei Li, ${ }^{5}$ Wu-Huei Hsu, ${ }^{2}$ \\ Shih-Jung Chen, ${ }^{6}$ Muh-Hwan Su, ${ }^{7}$ Shwu-Huey Liu, ${ }^{8}$ Yung-Chi Cheng, \\ Chih-Yi Chen, ${ }^{10}$ and Ming-Ching Kao ${ }^{3,11}$ \\ ${ }^{1}$ Graduate Institute of Clinical and Medical Science, School of Medicine, China Medical University, Taichung 40402, Taiwan \\ ${ }^{2}$ Division of Pulmonary and Critical Care, China Medical University Hospital, Taichung 40447, Taiwan \\ ${ }^{3}$ Department of Biological Science and Technology, College of Life Sciences, China Medical University, Taichung 40402, Taiwan \\ ${ }^{4}$ Pharmacy Department, China Medical University Hospital, Taichung 40447, Taiwan \\ ${ }^{5}$ Department of Pathology, Da-Chien General Hospital, Miaoli 36052, Taiwan \\ ${ }^{6}$ Luo-Gui-Ying Fungi Agriculture Farm, Taoyuan 33043, Taiwan \\ 7 Sinphar Group R\&D Center, Yilan 26944, Taiwan \\ ${ }^{8}$ Division of Drug Development, PhytoCeutica, Inc., New Haven, CT 06511-1989, USA \\ ${ }^{9}$ Department of Pharmacology, Yale University School of Medicine, New Haven, CT 06520-8066, USA \\ ${ }^{10}$ Division of Chest Surgery, China Medical University Hospital, Taichung 40447, Taiwan \\ ${ }^{11}$ Department of Biochemistry, National Defense Medical Center, Taipei 11490, Taiwan
}

Correspondence should be addressed to

Chih-Yi Chen, micc@www.cmuh.org.tw and Ming-Ching Kao, mckao@mail.cmu.edu.tw

Received 14 March 2012; Accepted 26 April 2012

Academic Editor: William C. S. Cho

Copyright () 2012 Yang-Hao Yu et al. This is an open access article distributed under the Creative Commons Attribution License, which permits unrestricted use, distribution, and reproduction in any medium, provided the original work is properly cited.

Ganoderma tsugae (GT) is a traditional Chinese medicine that exhibits significant antitumor activities against many types of cancer. This study investigated the molecular mechanism by which GT suppresses the growth of doxorubicin-resistant lung adenocarcinoma $\mathrm{H} 23 / 0.3$ cells. Our results reveal that GT inhibits the viability of $\mathrm{H} 23 / 0.3$ cells in vitro and in vivo and sensitizes the growth suppression effect of doxorubicin on $\mathrm{H} 23 / 0.3$ cells. The data also show that GT induces $\mathrm{S}$ phase arrest by interfering with the protein expression of cyclin A, cyclin E, CDK2, and CDC25A. Furthermore, GT induces cellular apoptosis via induction of a mitochondria/caspase pathway. In addition, we also demonstrate that the suppression of cell proliferation by GT is through downregulation of the PI3K/Akt signaling pathway. In conclusion, this study suggests that GT may be a useful adjuvant therapeutic agent in the treatment of lung cancer.

\section{Introduction}

Lung carcinoma is the most predominant form of cancer and has surpassed breast carcinoma as the leading cause of cancer mortality in the United States; it accounts for approximately $26 \%$ and $28 \%$ of all female and male cancer deaths, respectively [1]. Lung carcinoma was also the leading cause of cancer death in Taiwan for women and men in 2010 [2]. Moreover, an apparent increasing death rate of lung carcinoma from 1986 to 2010 has also been observed in Taiwan [2].
The two most aggressive forms of lung cancer are non-smallcell lung cancer (NSCLC) and small-cell lung cancer (SCLC), which account for approximately $85 \%$ and $15 \%$, respectively, of all lung cancers [3]. Both forms of lung cancer frequently cause drug resistance leading to poor survival [4]. Therefore, alternative medicines and more treatment modalities to overcome drug resistance and to improve the patients' outcomes of this serious disease are urgently desired.

Ganoderma, a traditional Chinese medicine (TCM), has been widely used for medicinal purposes in oriental 
countries for centuries. Ganoderma lucidum (GL) and Ganoderma sinense (GS), listed as Lingzhi in China pharmacopeia, are two of the most representative species of Ganoderma and have a long history of use in folk medicine in China. The biological activities of GL and GS, especially their immunomodulatory and antitumor properties, have been well documented [5]. In addition, Ganoderma tsugae (GT), another well-cultivated species of Ganoderma, has been investigated and found to possess many biological and pharmacological properties, such as antiinflammation [6], antifibrosis [7], antiautoantibody formation [8], and antioxidation [9]. A number of reports show that GT possess growth inhibition effects on a variety of tumor cells, such as sarcoma 180 cells [10], breast cancer MDA-MB-231 and MCF-7 cells [11], hepatoma Hep3B cells [12], and colorectal cancer COLO 205 cells [13]. Moreover, GT also exerts antiangiogenesis effects on epidermoid carcinoma A431 cells by modulating the EGFR/PI3K/Akt/mTOR signaling pathway [14]. Although GT exhibits anticancer activities in many human cancer cells, the molecular mechanisms that govern its inhibitory effect on the growth of lung cancer cells are still not clear and need to be explored.

The quality and quantity of TCMs, including Ganoderma, are potentially influenced by many factors, including the cultivation methods, the cultivated regions, the growth conditions, the processing procedures, and the formulated preparations [15]. Therefore, the quality control of TCMs must be established scientifically in terms of both the chemical and biological aspects; but to date, this has not been achieved. A newly established and actively progressed Chinese medicine-based academic organization, called the Consortium for Globalization of Chinese Medicine (CGCM; http://www.tcmedicine.org), is promoting and requesting the quality control of TCMs and also striving to explore the functional use of herbonomics.

In this study, we provide a quality assured ethanol extract of GT (GTE) and demonstrate its anticancer effects and related molecular mechanisms in doxorubicin-resistant NSCLC H23/0.3 cells in vitro and in vivo. Our results indicate that the GTE inhibits cellular growth and induces $S$ phase arrest and apoptosis by modulating the PI3K/Akt signaling pathway. Furthermore, we also show that GTE sensitizes $\mathrm{H} 23 / 0.3$ cells to doxorubicin, indicating a potential use of GTE in the treatment of lung cancer with drug resistance.

\section{Materials and Methods}

2.1. Cell Culture. Two non-small-cell lung cancer (NSCLC) cell lines were used in this study. H23 (CRL-5800, ATCC), a lung adenocarcinoma cell line, was purchased from ATCC (American Type Culture Collection). H23/0.3, a doxorubicin-resistant $\mathrm{H} 23$ cell line, was a gift from Dr. Chun-Ming Tsai (Department of Chest, Veterans General Hospital, Taipei, Taiwan); the cell line was generated by the stepwise exposure of $\mathrm{H} 23$ to increasing concentrations of doxorubicin up to $0.3 \mu \mathrm{g} / \mathrm{mL}$. All cells were cultured in RPMI-1640 medium (Gibco BRL) supplemented with 10\% fetal bovine serum in a humidified atmosphere with $5 \% \mathrm{CO}_{2}$ at $37^{\circ} \mathrm{C}$.

2.2. Chemicals and Antibodies. The anticytochrome c antibody and propidium iodide (PI) were obtained from Sigma-Aldrich Co. (St. Louis, MO, USA). The antibodies against cyclin A, cyclin E, Akt1, Bax, and caspase-3 were purchased from Santa Cruz Biotechnology (Santa Cruz, CA, USA). The anti-PARP antibody was obtained from Biovision Inc. (Mountain View, CA, USA). The antibodies against Bcl-2, CDK2, CDC25A, CDC25B, and CDC25C were purchased from Abcam, Inc. (Cambridge, MA, USA). The anti-phospho-Akt (Thr473) antibody, the horseradish peroxidase-conjugated anti-rabbit and anti-mouse $\operatorname{IgG}$ antibodies, and the PI3K inhibitor (LY294002) were purchased from Cell Signaling Technology, Inc. (Beverly, MA, USA). The anti- $\beta$-actin antibody was purchased from Chemicon International, Inc. (Temecula, CA, USA). The IRDye 800conjugated affinity purified anti-rabbit and anti-mouse IgGs were purchased from Rockland Immunochemicals, Inc. (Gilbertsville, PA, USA). Doxorubicin was purchased from Pharmacia (Pharmacia \& Upjohn S.P.A. Milan, Italy).

\subsection{Preparation of Ganoderma tsugae Extracts. Ganoderma} tsugae (GT) was kindly provided by the Luo-Gui-Ying Fungi Agriculture Farm (with a registered name of Tien-Shen Lingzhi), Taoyuan, Taiwan. Briefly, the powder of the GT fruiting body $(20 \mathrm{~g})$ was soaked in $99.9 \%$ ethanol $(400 \mathrm{~mL})$, mixed, and shaken for $24 \mathrm{~h}$ with a rotating shaker. After centrifugation, the supernatant was filtered through filter paper (Whatman, Cat. No. 1001-110), and the residues were extracted with alcohol two additional times as mentioned above. The filtrates were collected and subjected to concentration under reduced pressure (i.e., evaporated to dryness under reduced pressure) to produce a brown gel-like GT extract (GTE). The yield was approximately $10 \%$. The GTE was then prepared as a stock solution with ethanol solvent $(200 \mathrm{mg} / \mathrm{mL})$ and stored at $-20^{\circ} \mathrm{C}$ until use.

2.4. High-Performance Liquid Chromatography (HPLC). Sample preparation: the sample was diluted, by the addition of ethanol to $1.0 \mathrm{mg} / \mathrm{mL}$, and filtered through a $0.2 \mu \mathrm{m}$ Millipore filter; then, $10 \mu \mathrm{L}$ of the sample was subjected to HPLC analysis. Sample separation: the sample $(10 \mu \mathrm{L})$ was automatically delivered into a C-18 column (LiChroCART, $250 \times 4.6 \mathrm{~mm}, 5 \mu \mathrm{m}$, Merck, Germany) for separation via an HPLC system (L-7100 pump and L-7400 UV-vis detector, Hitachi, Tokyo, Japan). The initial mobile phase comprised acetonitrile (30\%) and phosphoric acid $(0.11 \%, \mathrm{pH} 2.2)$ with a flow rate of $1 \mathrm{~mL} / \mathrm{min}$; the percentage of acetonitrile in the mobile phase was increased from $30 \%$ to $100 \%$ in a linear gradient for the first 20 minutes and then maintained at $100 \%$ until the end of the experiment. The detection of signals was set at wavelength of $288 \mathrm{~nm}$.

2.5. Electrospray Ionization Mass Spectrometry (ESI-MS). GTE was dissolved in ethanol $(10 \mathrm{ng} / \mu \mathrm{L})$, and the resulting solution was directly injected into the ion source (Esquire 


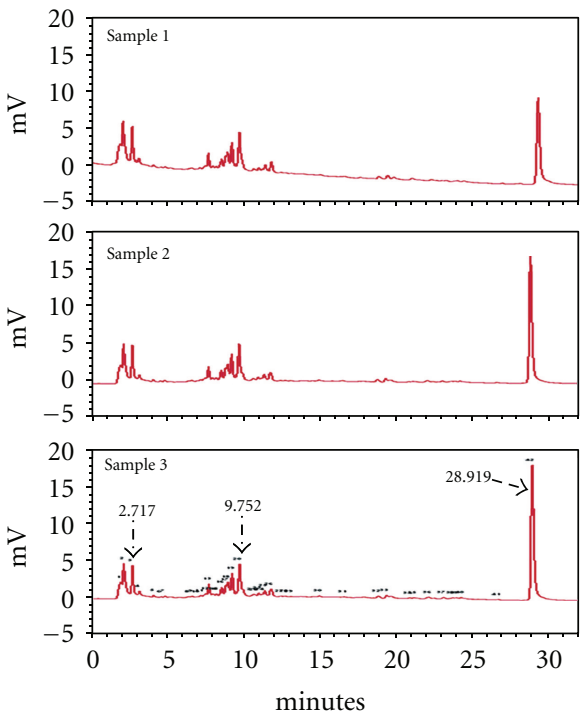

(a)

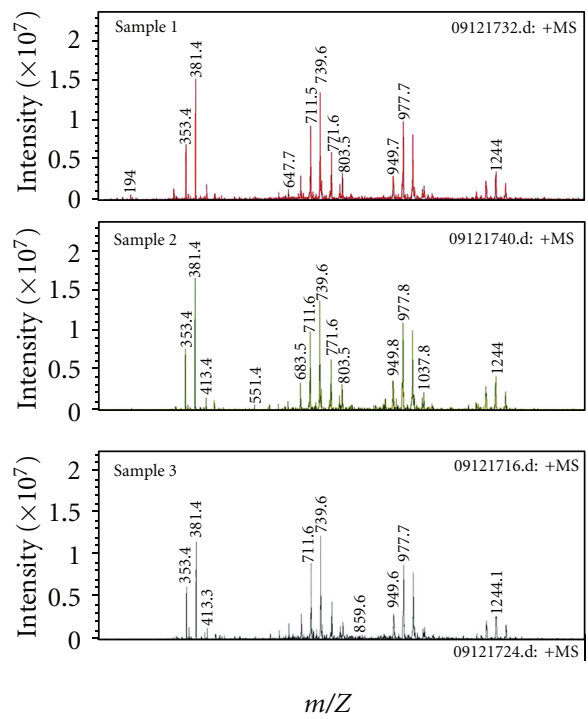

(b)

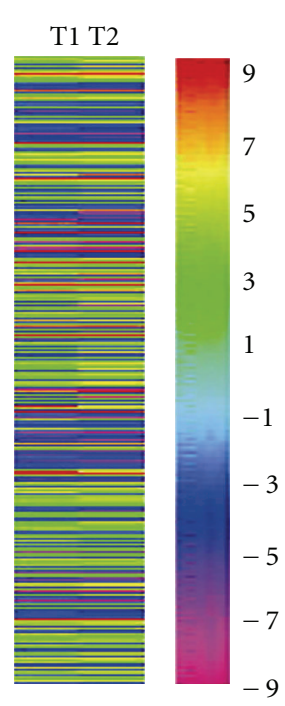

(c)

FIGURE 1: Quality control of GTE. (a) The 3 GTE samples were derived from the fruiting bodies of an improved strain of Ganoderma tsugae that were collected at three different times. The HPLC chromatogram shows all of the peaks of the components that eluted before 32 minutes. The chemical fingerprints were found to be identical for the 3 batches, and the specific retention time was given in one example. (b) The identical mass fingerprints were also confirmed using ESI-MS. (c) The biological responses for GTE acting on H23/0.3 analyzed by Phytoviewer QC using the whole genomic approach in duplicate experiments (T1, T2) show highly concordant bioresponse fingerprints with a PSI value of 0.98 .

HCT ultra PTM, Bruker) using ESI (positive mode) at a flow rate of $240 \mu \mathrm{L} / \mathrm{min}$. The mass range was acquired from 100 to $1,000 \mathrm{~m} / \mathrm{z}$.

\subsection{Quality Control of GTEs via Bioresponse Fingerprinting.} To maintain and assess the quality of the GT extracts (GTEs), a comprehensive platform for quality control of botanical drugs, named PhytomicsQC [16], was used in this study. In addition to the chemical fingerprinting method (e.g., HPLC \& ESI-MS) as mentioned above, a biological response fingerprinting method from the PhytomicsQC technology [16] was also performed in this study. Briefly, the bioresponse is measured by defining the set of genes that are significantly regulated in cell cultures treated with the GTE. We used optimized standard operating procedures at every step, including cell banking, tissue culture, botanical extractions, cell culture treatments, and RNA extractions. The RNA is used to obtain transcription profiles in GeneChip hybridization studies using Affymetrix technology. The changes in the individual gene expression levels obtained by the GeneChip experiments were measured by Affymetrix MAS 5.0 software. A statistical pattern comparison method from the PhytomicsQC platform, phytomics similarity index (PSI), was applied to determine the batch-to-batch similarity of the botanical products. In general, clinically similar batches have a PSI of 0.95 or more. The genomic bioresponse to the GTEs was determined in $\mathrm{H} 23 / 0.3$ cells treated with a single $\mathrm{IC}_{50}$ dose of GTE for $24 \mathrm{~h}$. The total RNA was extracted from the GTEtreated cells and cleaned with a commercial kit (Qiagene RNA extraction kit, cat\# 75144). The quality of the GTEs was then assessed, and the samples were submitted to the
National Yang-Ming University Genome Core Laboratory (Taipei, Taiwan) for GeneChip Hybridization experiments. These experiments were repeated independently in duplicate.

2.7. Cell Proliferation Assay. Cell proliferation was determined using the MTT metabolic assay as described previously [17]. Briefly, cells were plated onto 96-well microtiter plates $\left(1 \times 10^{3}-1 \times 10^{4}\right.$ cells/well, depending on the cancer cells used). After the cells adhered to the plates, various doses of GTE were applied to the cells, and the cells were incubated at $37^{\circ} \mathrm{C}$ for $72 \mathrm{~h}$. At the end of the GTE treatment, the media were aspirated, and the cells were incubated for $4 \mathrm{~h}$ in fresh media containing MTT reagent $(0.5 \mathrm{mg} / \mathrm{mL})$. Finally, the solution was measured spectrophotometrically at $545 \mathrm{~nm}$ against a reference wavelength of $690 \mathrm{~nm}$.

2.8. Flow Cytometric Analysis. For the analysis of the cell cycle, the phase distribution was detected by flow cytometry as described previously [17]. After the GTE treatment, the cells were trypsinized, washed with PBS, and fixed with $75 \%$ ethanol overnight at $-20^{\circ} \mathrm{C}$. The fixed cells were washed with PBS and treated with a working solution of propidium iodide (PI) $(50 \mu \mathrm{g} / \mathrm{mL}$ PI in PBS plus $1 \%$ Tween-20 and $10 \mu \mathrm{g}$ RNase) for $30 \mathrm{~min}$ in the dark at room temperature to stain the cells for subsequent analysis. The DNA contents were measured using flow cytometry (BD FACS Canto). The cell cycle distribution was analyzed with the FCS Express v2.0 software. For the analysis of apoptosis, the cells were stained using the Annexin V-FITC Apoptosis Detection Kit I (BD Biosciences, San Diego, CA) according 


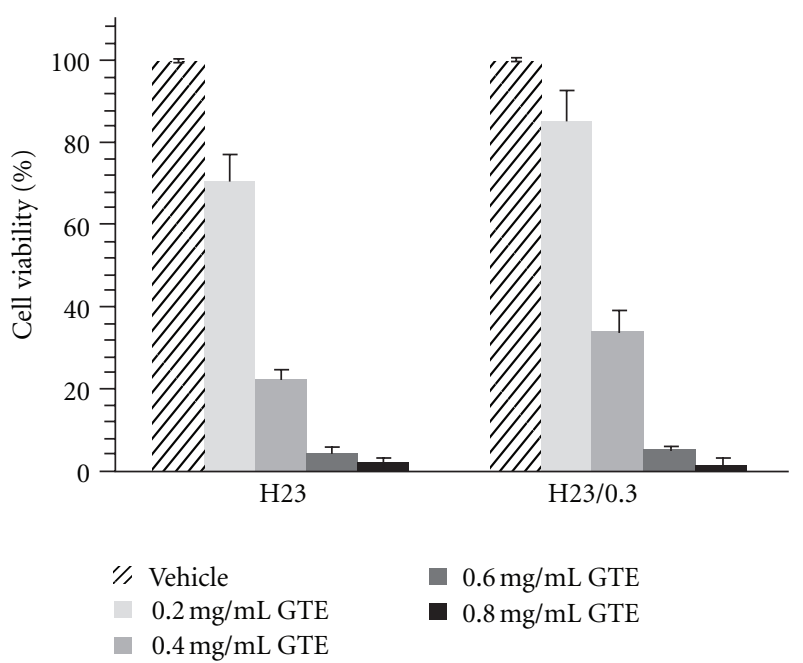

(a)
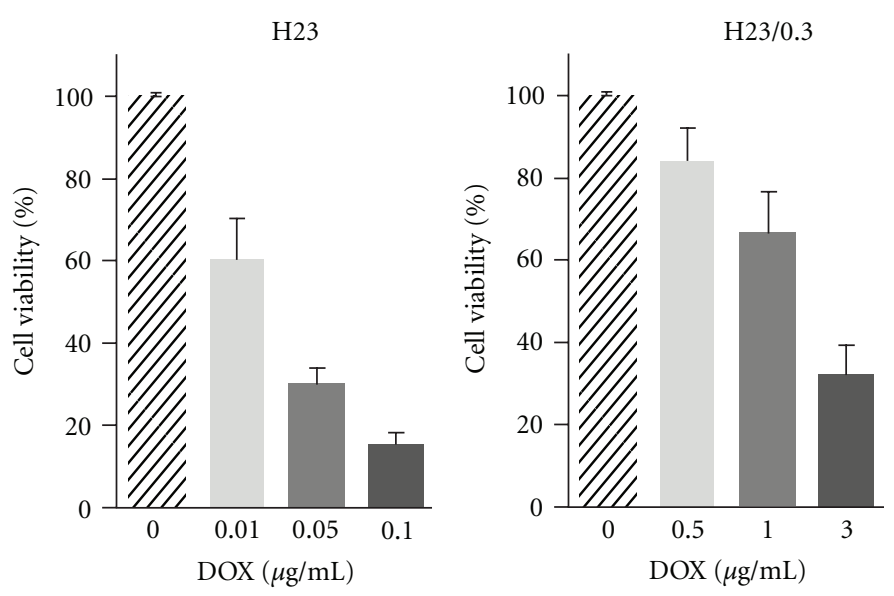

(b)

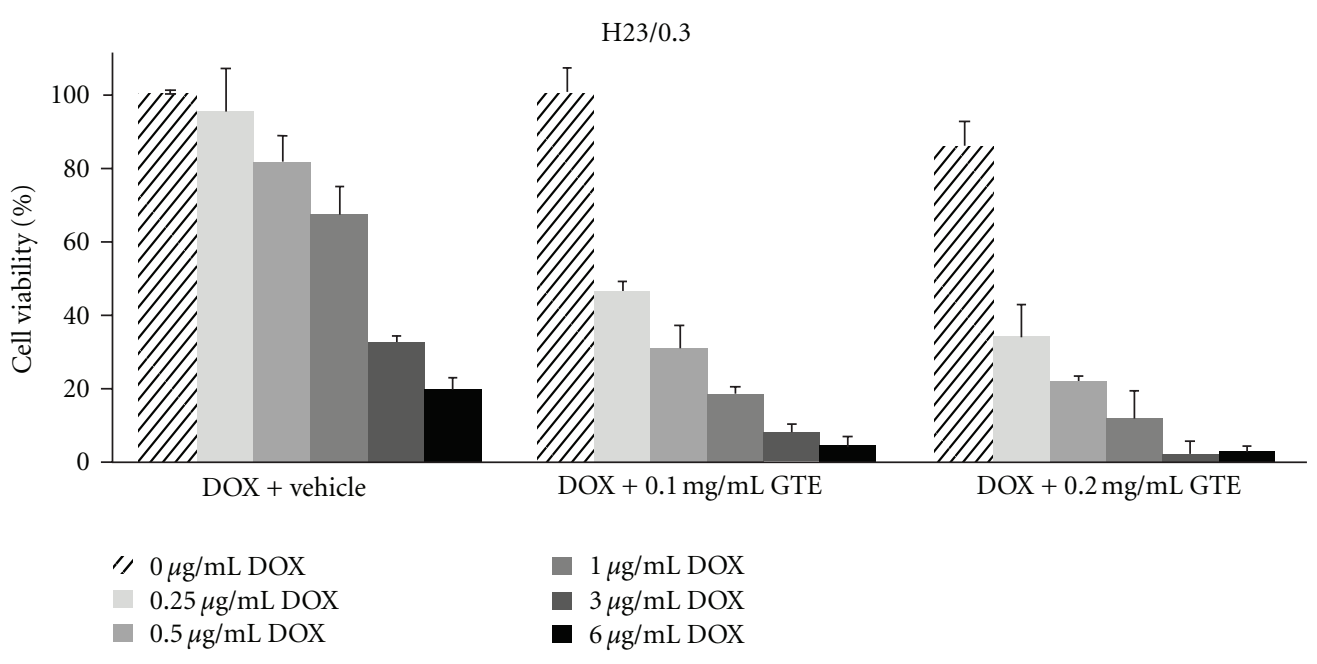

(c)

FIGURE 2: Effect of GTE on cell viability in doxorubicin-resistant lung adenocarcinoma H23/0.3 cells. (a) H23 and H23/0.3 cells were treated with either vehicle control or GTE $(0.2 \mathrm{mg} / \mathrm{mL}, 0.4 \mathrm{mg} / \mathrm{mL}, 0.6 \mathrm{mg} / \mathrm{mL}$, or $0.8 \mathrm{mg} / \mathrm{mL})$ for $72 \mathrm{~h}$. Cell viability was determined using the MTT assay as described in the Section 2. (b) $\mathrm{H} 23$ and $\mathrm{H} 23 / 0.3$ cells were treated with various concentrations of doxorubicin $(0.01-0.1 \mu \mathrm{g} / \mathrm{mL}$ in $\mathrm{H} 23$ cells; $0.5-3 \mu \mathrm{g} / \mathrm{mL}$ in $\mathrm{H} 23 / 0.3$ cells) for $72 \mathrm{~h}$. Cell viability was determined using the MTT assay. (c) H23/0.3 cells were treated with various concentrations of doxorubicin $(0 \mu \mathrm{g} / \mathrm{mL}, 0.25 \mu \mathrm{g} / \mathrm{mL}, 0.5 \mu \mathrm{g} / \mathrm{mL}, 1 \mu \mathrm{g} / \mathrm{mL}, 3 \mu \mathrm{g} / \mathrm{mL}$, and $6 \mu \mathrm{g} / \mathrm{mL})$ with or without GTE $(0.1 \mathrm{mg} / \mathrm{mL}$ or $0.2 \mathrm{mg} / \mathrm{mL}$ ) for $72 \mathrm{~h}$. Cell viability was determined by the MTT assay. Results are expressed as the mean \pm SD of three independent experiments.

to the manufacturer's recommendation. The amount of apoptotic cells was determined by flow cytometry (BD FACS Canto) and analyzed by the FCS Express v2.0 software.

2.9. Immunofluorescence Microscopy. H23/0.3 cells $\left(2 \times 10^{5}\right.$ cells) were treated with GTE for $24 \mathrm{~h}$ and washed with cold DPBS. Then, the Annexin V-FITC Apoptosis Detection Kit I reagent was added to the cells according to the manufacturer's protocol and incubated for $15 \mathrm{~min}$ at room temperature in the dark. Photomicrographs were obtained with a Leica TCS SP2 Confocal Spectral Microscope [18]. We also used a fluorescence microscope (Leica DMR) to identify the fragmented and condensed nuclei that were stained with DAPI (4', 6' diamidino-2-phenylindole).

2.10. Western Blot Analysis. To determine the changes at the protein level after the GTE treatment, the cells were lysed in RIPA buffer (50 mM Tris- $\mathrm{HCl}, \mathrm{pH} 7.2,150 \mathrm{mM}$ EDTA, 1\% Nonidet P-40, 0.05\% SDS, $1 \mathrm{mM}$ PMSF and $1 \mathrm{mM}$ leupeptin). The cell lysates were centrifuged at $14,000 \times \mathrm{g}$ for $10 \mathrm{~min}$ at $4^{\circ} \mathrm{C}$. The supernatant was analyzed by SDSPAGE and blotted onto a polyvinyldenefluoride (PVDF) membrane. The membrane was subsequently incubated with the specified primary antibody and then incubated with the HRP-conjugated or the IRDye 800-conjugated secondary 


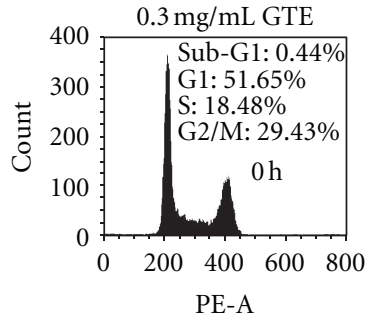

PE-A

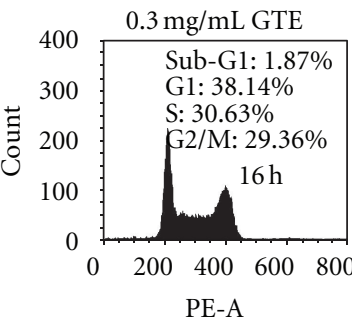

PE-A
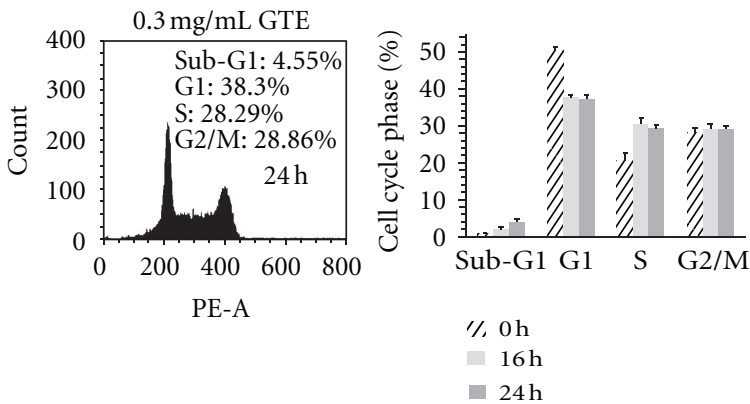

(a)
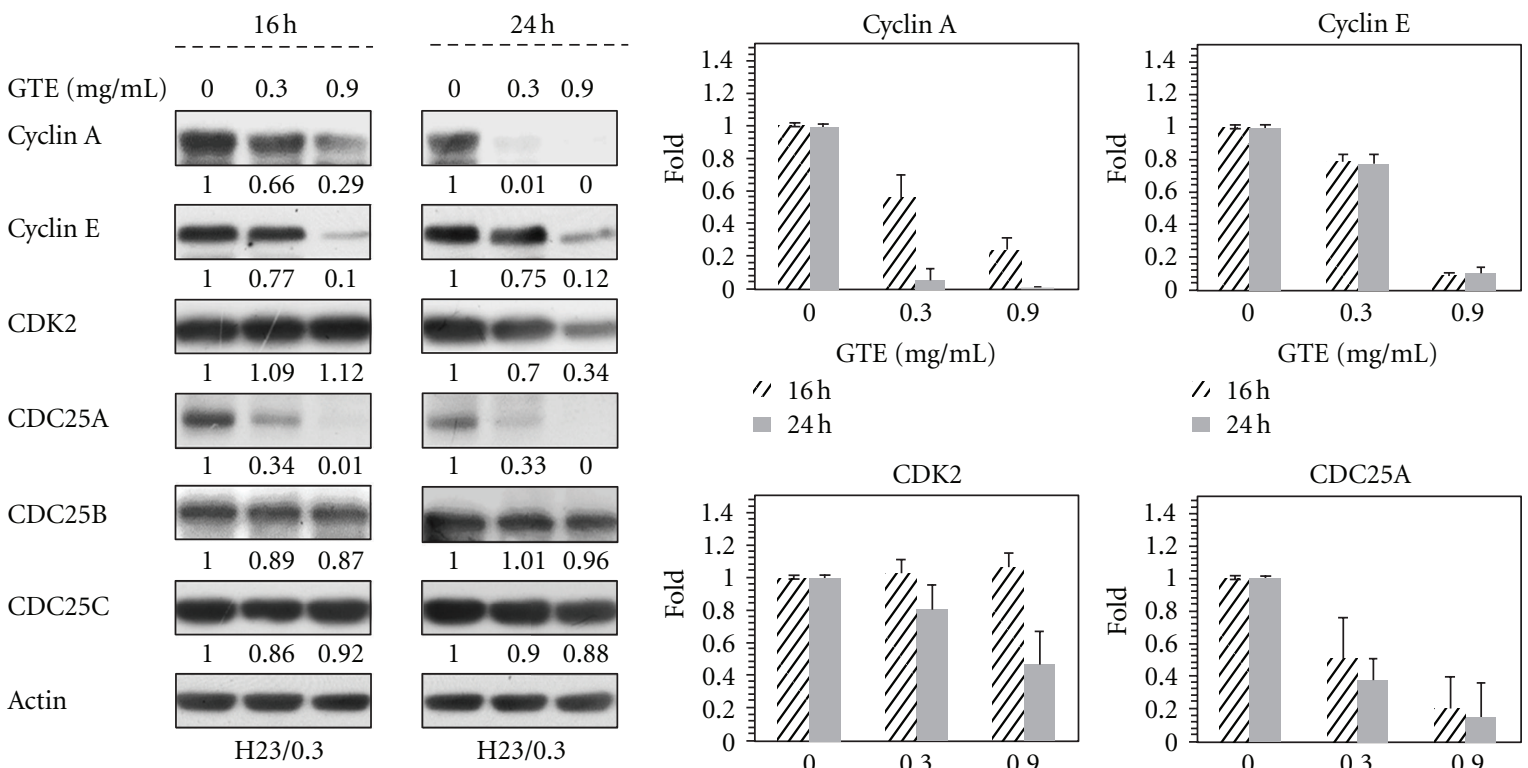

- $24 \mathrm{~h}$
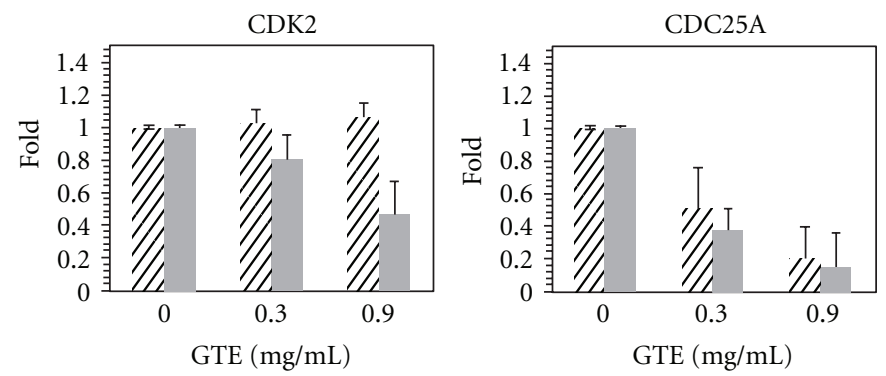

$$
\begin{aligned}
& \text { / } 16 \mathrm{~h} \\
& \square 24 \mathrm{~h}
\end{aligned}
$$$$
\begin{aligned}
& \% 16 \mathrm{~h} \\
& \square 24 \mathrm{~h}
\end{aligned}
$$

(c)

Figure 3: Effect of GTE on cell cycle distribution in H23/0.3 cells. (a) H23/0.3 cells were treated with GTE ( $0.3 \mathrm{mg} / \mathrm{mL})$ for 16 and $24 \mathrm{~h}$. The cell cycle distribution was measured by flow cytometry as described in Section 2. The error bars indicate the standard deviations of each phase (\%), which were the means of three independent experiments. (b) H23/0.3 cells were treated with various concentrations of GTE $(0 \mathrm{mg} / \mathrm{mL}, 0.3 \mathrm{mg} / \mathrm{mL}$, and $0.9 \mathrm{mg} / \mathrm{mL})$ for $16 \mathrm{~h}$ and $24 \mathrm{~h}$. The expression of S phase regulators was determined by Western blotting as described in Section 2. (c) A histogram showing the relative protein levels from (b). Results are expressed as the mean \pm SD of three independent experiments.

antibody. Reactive signals were visualized with an Enhanced Chemiluminescence Kit (Amersham Biosciences, Arlington Heights, IL) or the Odyssey Infrared Imaging System (LICOR Biosciences, Cambridge, UK).

2.11. Release of Cytochrome c. The release of cytochrome c $(\mathrm{Cyt}-\mathrm{c})$ from the mitochondria to the cytosol was detected as described previously [17]. Briefly, the cells were gently lysed in lysis buffer ( $1 \mathrm{mM}$ EDTA, $20 \mathrm{mM}$ Tris-HCl, $\mathrm{pH}$ 7.2, $250 \mathrm{mM}$ sucrose, $1 \mathrm{mM}$ dithiothreitol, $1.5 \mathrm{mM} \mathrm{MgCl}_{2}$, $10 \mathrm{mM} \mathrm{KCl}, 10 \mu \mathrm{g} / \mathrm{mL}$ leupeptin, $5 \mu \mathrm{g} / \mathrm{mL}$ pepstatin A, and $2 \mu \mathrm{g} / \mathrm{mL}$ aprotinin). The cell lysates were centrifuged at $12,000 \times \mathrm{g}$ at $4^{\circ} \mathrm{C}$ for $10 \mathrm{~min}$ to obtain the pellets (the fractions that contained mitochondria) and the supernatants (cytosolic extracts free of mitochondria). The protein content of the supernatant was determined by the Bio-Rad protein assay kit. The protein $(20 \mu \mathrm{g})$ was resolved by SDSPAGE (14\%) and then transferred onto PVDF membranes for the detection of Cyt-c.

2.12. Animal Experiments. The animal experiments were performed as described previously [13] with slight modifications. Briefly, $1 \times 10^{6} \mathrm{H} 23 / 0.3$ cells were subcutaneously implanted into the flank region of nude mice. In total, 26 mice were enrolled in this experiment, 20 tumor-implanted mice were treated with $(n=10)$ and without $(n=10)$ GTE, 


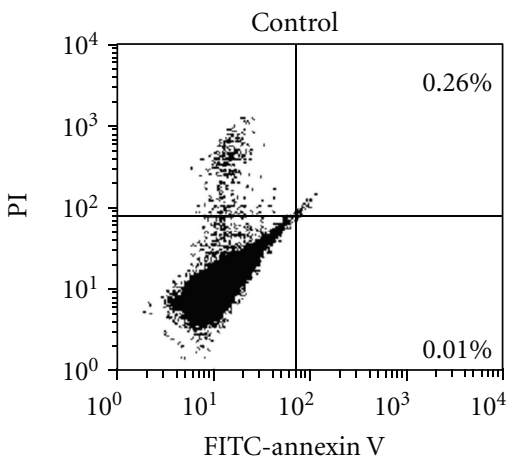

FITC-annexin V

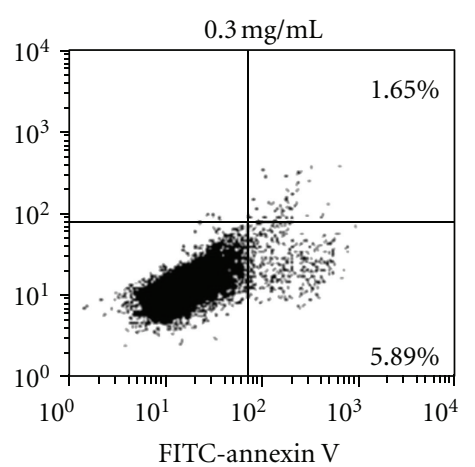

(a)

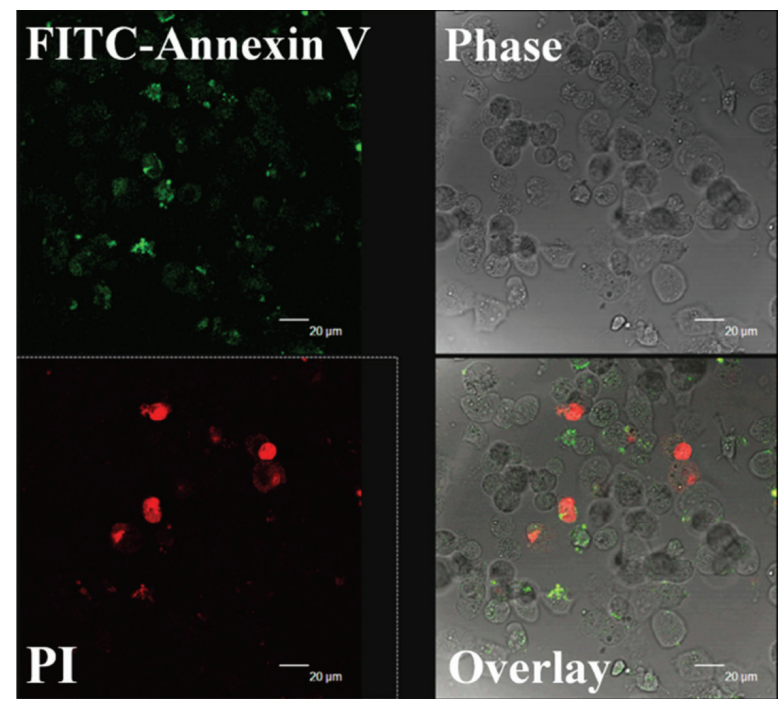

(b)
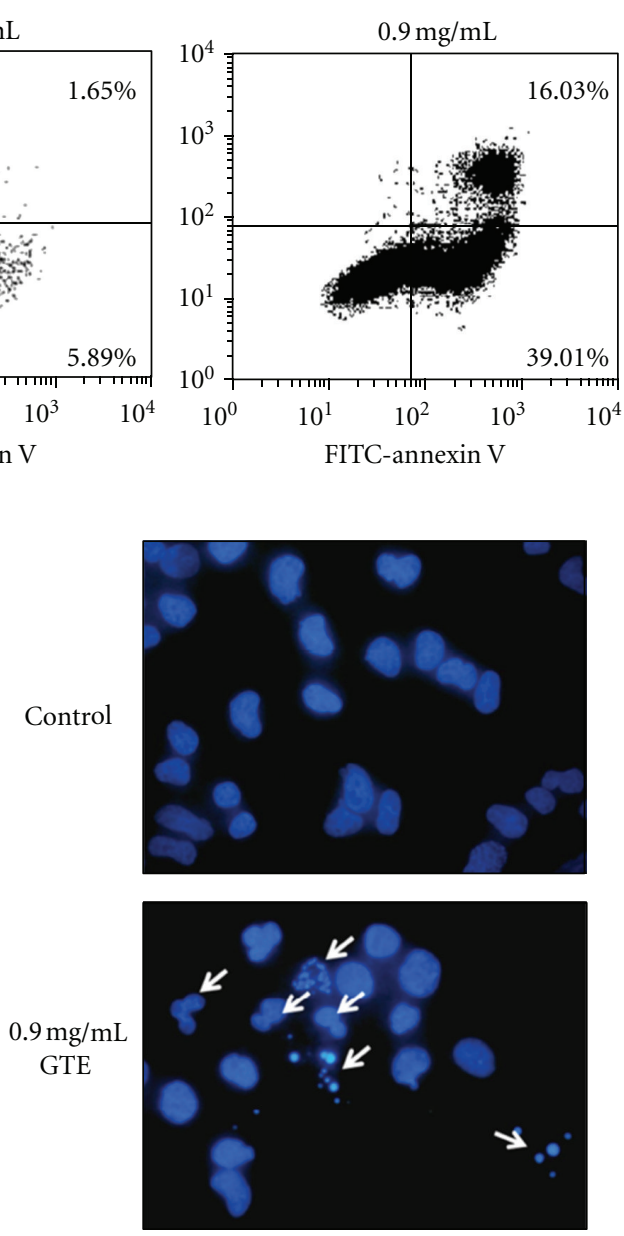

(c)

FIGURE 4: Effect of GTE on cellular apoptosis in H23/0.3 cells. (a) H23/0.3 cells were treated with various concentrations of GTE ( 0 mg/mL, $0.3 \mathrm{mg} / \mathrm{mL}$, and $0.9 \mathrm{mg} / \mathrm{mL}$ ) for $24 \mathrm{~h}$. Cellular apoptosis was measured by flow cytometry using the FITC-conjugated annexin V and PI double stains as described in Section 2. (b) H23/0.3 cells were treated with $0.9 \mathrm{mg} / \mathrm{mL}$ of GTE for $24 \mathrm{~h}$. The exposure of phosphatidylserine (PS) was measured by confocal microscopy with annexin V-FITC (green color, stained for early asymmetry membrane) and PI (red color, stained for nuclear chromosome after cell membrane disruption) double stains. (c) H23/0.3 cells were treated with $0.9 \mathrm{mg} / \mathrm{mL}$ of GTE for $24 \mathrm{~h}$. Fragmented condensed nuclei were measured using a DAPI staining assay.

respectively, and the remaining 6 mice were neither tumorimplanted nor GTE-treated and were used as a reference control. The GTE-treated mice were fed with GTE daily at a dose of $100 \mathrm{mg} / \mathrm{kg}$ body weight; this feeding schedule was initiated when the developed tumor was approximately $50 \mathrm{~mm}^{3}$ in volume (usually 2-3 weeks after the cancer cells were implanted). The tumor volume and body weight were measured every 3 days. The mice were sacrificed for pathological examination when the tumor volume exceeded $2,000 \mathrm{~mm}^{3}$. The tumors were then completely excised from the subcutaneous tissue and weighed. Biochemical and hematological measurements were evaluated for the toxicity test of the drug.

2.13. Immunohistochemical Staining. Fourteen H23/0.3xenografted tumors (seven for each of the GTE-free and GTE-treated groups) and the surrounding mouse tissues were completely excised, fixed in $10 \%$ neutral buffered formalin, embedded in paraffin, and sliced for hematoxylin and eosin (H\&E) staining to measure the extent of mitotic and necrotic figures. The preparation of samples for $\mathrm{H} \& \mathrm{E}$ staining was performed as described previously [13]. Five high-power fields (5 HPFs, 400X) of H\&E-stained slides were counted using the image selection function of Adobe Photoshop, Version 7.0 (Adobe Systems, CA). The number of mitotic figures was counted in 5 HPFs of H\&E-stained, necrosis-free areas.

2.14. Statistical Analysis. For statistical analysis, the items of cell death percentage and mitoses were calculated with the Mann-Whitney $U$ test. The differences in tumor growth were determined by multiple response models, and the tumor weights were compared by the two sample $t$-test. Statistical Products and Services Solution software (SPSS, version 10.0, SPSS UK Ltd., Woking, Surrey, UK) was used for the analysis. Significant levels were set as $P<0.05$. 


\section{Results}

3.1. Quality Control of GTE Using Chemical and Bioresponse Fingerprint Analyses. Three batches of GT fruiting bodies that were collected from the same fungi farm at different times were extracted with ethanol. The chemical profiles of the GTEs were analyzed using high-performance liquid chromatography (HPLC). The fingerprints of the 3 batches of GTE were almost identical in triplet experiments. Three representative fingerprints located at 2.717 minutes, 9.752 minutes, and 28.919 minutes were indicated based on their retention times (Figure 1(a)). The last part of the chromatogram corresponded with the major compounds of GTE and had a peak area of $47 \%$ (the specific elution time and peak area are based on one representative sample, sample 2). We further verified the chemical profiles of the GTEs with electrospray ionization mass spectrometry (ESI-MS). Similarly, the MS fingerprints for the 3 batches of samples were also indistinguishable (Figure 1(b)). In addition, the bioresponse fingerprints were analyzed by the pattern comparison method of the PhytomicsQC platform, which showed highly concordant biological responses for GTE acting on H23/0.3 cells with a PSI value of 0.98 . Under this PSI value, the bioresponse fingerprints contain 338 specifically altered expressed genes with 178 upregulations and 160 downregulations (Figure 1(c)). These results suggest that the GT powder products used in this study have stable, consistent, and high quality.

3.2. GTE Suppresses the Growth of Doxorubicin-Resistant H23/0.3 Cells. To ascertain whether GTE inhibits the growth of lung adenocarcinoma $\mathrm{H} 23$ and $\mathrm{H} 23 / 0.3$ cells, we first determined the viability of cells exposed to GTE using the MTT assay. As shown in Figure 2(a), the GTE treatment resulted in a dose-dependent inhibition of cell viability, accounting for a $28-97 \%$ and $5-98 \%$ reduction in the number of viable cells after treatment with various concentrations of GTE $(0.2-0.8 \mathrm{mg} / \mathrm{mL})$ for $72 \mathrm{~h}$ in $\mathrm{H} 23$ and $\mathrm{H} 23 / 0.3$ cells, respectively. The $\mathrm{IC}_{50}$ of GTE was approximately $0.29 \mathrm{mg} / \mathrm{mL}$ for $\mathrm{H} 23$ cells and $0.34 \mathrm{mg} / \mathrm{mL}$ for $\mathrm{H} 23 / 0.3$ cells. The results suggest that GTE is capable of suppressing the proliferation of lung adenocarcinoma $\mathrm{H} 23$ and $\mathrm{H} 23 / 0.3$ cells with no selectivity on either cell.

Resistance to anticancer drugs (e.g., doxorubicin and cisplatin) is a major problem in the treatment of patients with lung cancer [19]. We, therefore, examined whether GTE could enhance/sensitize the growth inhibition effects of the anticancer drug doxorubicin in the doxorubicinresistant $\mathrm{H} 23 / 0.3$ cells (Figure 2(b)), by incubating that cell line with both doxorubicin and GTE. As illustrated in Figure 2(c), GTE significantly enhanced/sensitized the growth suppression effect of doxorubicin on $\mathrm{H} 23 / 0.3$ cells. We found that the number of viable cells was reduced by $14 \%$ in cells exposed to GTE $(0.2 \mathrm{mg} / \mathrm{mL})$ alone, by $18 \%$ in cells exposed to doxorubicin $(0.5 \mu \mathrm{g} / \mathrm{mL})$ alone, and by $78 \%$ in cells exposed to both agents combined. Similarly, we also discovered that GTE could enhance the chemotherapeutic efficacy of anticancer drugs against other lung cancer cell lines, for example, H23, A549, and CL1-0 (our unpublished data). These results clearly demonstrate that GTE is able to chemosensitize lung cancer cells to anticancer drugs such as doxorubicin.

3.3. GTE Induces S Phase Arrest by Modulating the Expression of Cell Cycle Regulatory Proteins. As mentioned above, our results showed a growth suppression effect of GTE on H23/0.3 cells (Figure 2(a)). To verify that the growth inhibition effect of GTE was due to the disruption of the cell cycle, flow cytometry was used to analyze the cell cycle distribution of H23/0.3 cells. As shown in Figure 3(a), the GTE treatment resulted in a marked cell cycle arrest at S phase, which accounted for $12 \%$ and $10 \%$ increases in the numbers of S phase cells after $16 \mathrm{~h}$ and $24 \mathrm{~h}$ of treatment with GTE, respectively. This increase in the population of S phase cells was accompanied by an attendant decrease in the G1 phase cell population. These findings suggest that GTE suppresses the growth of $\mathrm{H} 23 / 0.3$ cells by modulating the progression of the cell cycle.

Different regulatory proteins, such as cyclins, cyclindependent kinases (CDKs), and cell division cycle 25 (CDC25), work in multiple pathways to tightly modulate the progression of the cell cycle [20]. To identify the molecular mechanisms that govern the GTE-induced S phase arrest, we assessed the effect of GTE on the expression of cell cycle regulators involving in $\mathrm{S}$ phase progression. We found that treatment with GTE had a marked dose- and time-dependent inhibitory effect on the protein expression of cyclin A, cyclin E, CDK2, and CDC25A (Figures 3(b) and 3(c)). However, GTE treatment did not cause significant changes in the protein levels of CDC25B and CDC25C (Figures 3(b) and $3(c)$ ). These results suggest that GTE induces $S$ phase cell cycle arrest by modulating the protein expression of cell cycle regulatory proteins in $\mathrm{H} 23 / 0.3$ cells.

3.4. GTE Induces Cellular Apoptosis. The suppression of cell proliferation can be achieved by inhibiting cell cycle progression or by inducing cellular apoptosis [21, 22]. To further determine if GTE also induced cellular apoptosis, we analyzed the percentages of apoptotic cells by flow cytometry in $\mathrm{H} 23 / 0.3$ cells following staining with annexin V-FITC and PI. Apoptotic cells were shown in the upper right (as late apoptotic cells) or lower right (as early apoptotic cells) quadrants of the FACS histogram. We found that the treatment of H23/0.3 cells with $0.9 \mathrm{mg} / \mathrm{mL}$ of GTE resulted in a marked induction of apoptosis at both the early (39\%) and late (16\%) stages of apoptosis (Figure 4(a)). Confocal images clearly demonstrated that the translocation of phosphatidylserine (PS) from the inner leaflet of the plasma membrane to the cell surface, an early feature of cellular apoptosis, was induced by GTE treatment (Figure 4(b)). Additionally, fragmented and condensed nuclei were also identified by fluorescence microscopy with DAPI staining (Figure 4(c)). These observations suggest that GTE induces cell apoptosis in $\mathrm{H} 23 / 0.3$ cells.

3.5. GTE Activates the Mitochondria/Caspase Pathway. To determine the underlying molecular mechanisms that are 
TABLE 1: A comparison of the organ toxicity of the control and GTE treatment.

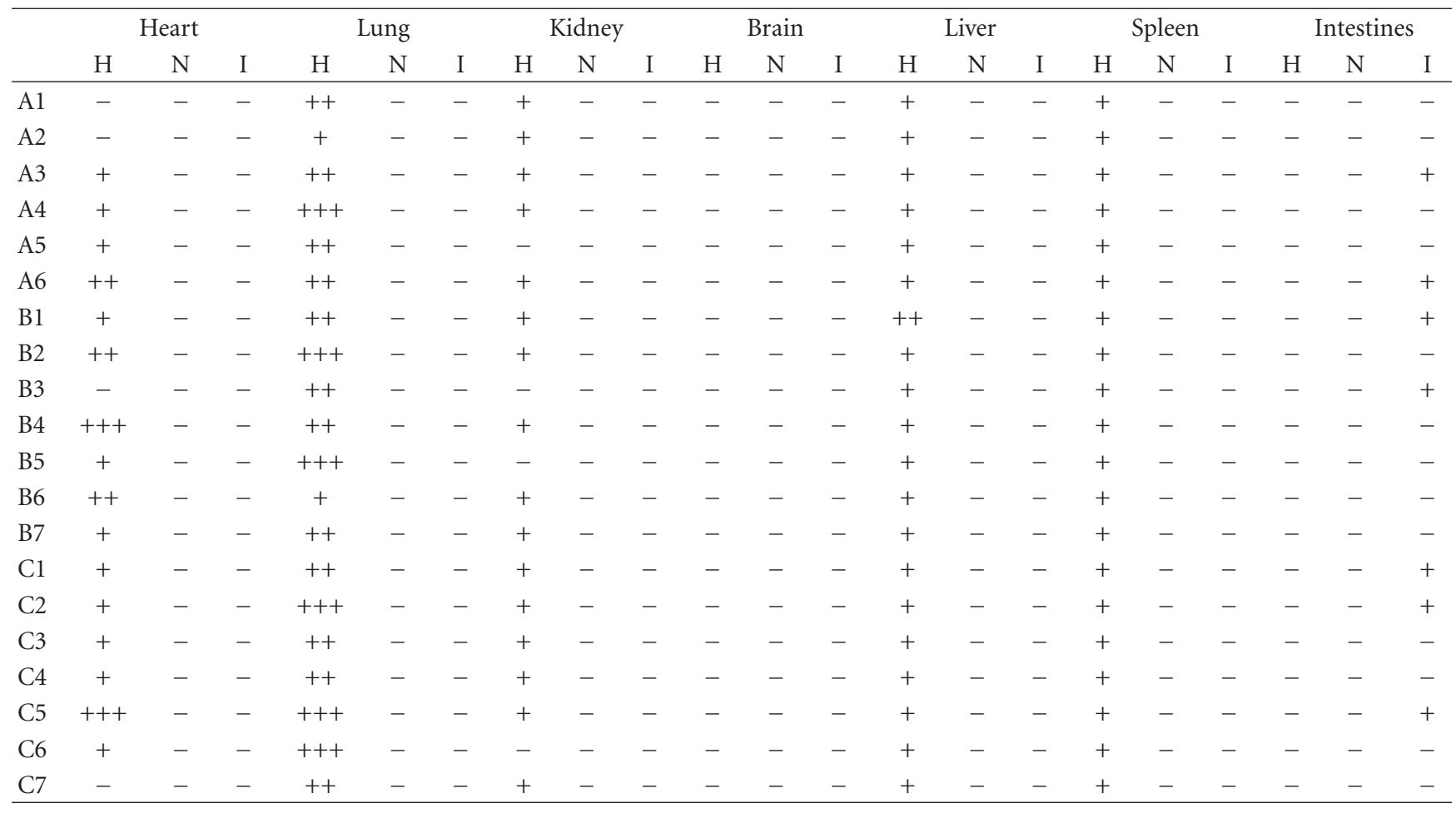

A1-6: mice that received neither a tumor implant nor GTE treatment; B1-7: mice that received a tumor implant but did not receive GTE treatment; C1-7: mice that received both a tumor implant and GTE treatment; H: hemorrhage; N: necrosis; I: Inflammation. The severity of the visual scoring system represented by "-" and "+"; - stands for none, + stands for minimal, ++ stands for visible, and +++ stands for apparent pathological change.

responsible for GTE-induced cell apoptosis, we examined the influence of GTE on the protein levels of members of the Bcl-2 family that mediate the activation of the mitochondria/caspase pathway [23]. As shown in Figure 5(a), GTE treatment resulted in a marked increase in the protein level of the proapoptotic protein Bax; however, treatment did not cause significant changes in the protein expression of the antiapoptotic protein $\mathrm{Bcl}-2$. Moreover, we examined the effect of GTE on the release of Cyt-c and found that GTE caused a significant increase of Cyt-c protein in the cytosolic fractions (Figure 5(b)). In addition, treatment with GTE also caused a significant cleavage of caspase- 3 and PARP (Figure 5(c)). These results demonstrate that GTE induces cell apoptosis by activating the mitochondria/caspase pathway in H23/0.3 cells.

3.6. GTE Inhibits Cell Proliferation via the PI3K/Akt Signaling Pathway. The PI3K/Akt signaling pathway is associated with cell proliferation, survival, and drug resistance in lung cancer [24]; therefore, we analyzed the influence of GTE on the PI3K/Akt signaling pathway. As shown in Figure 6(a), GTE exhibited dose- and time-dependent inhibitory effects on the levels of phospho-Akt and Akt. We next tested the validity of our results by incubating $\mathrm{H} 23 / 0.3$ cells with the PI3K inhibitor LY294002. The results revealed that LY294002 downregulated not only the protein levels of cyclin A but also the expression of cyclin E protein in $\mathrm{H} 23 / 0.3$ cells (Figure 6(b)). In other words, LY294002 exhibited an inhibitory effect that was similar to that of GTE on $\mathrm{H} 23 / 0.3$ cells. These data indicate that GTE inhibits cell proliferation by inhibiting the PI3K/Akt signaling pathway in H23/0.3 cells.

3.7. GTE Inhibits the Growth of H23/0.3 Xenografted Tumors. To verify the in vivo antitumor effect of GTE, we used xenografted tumor-bearing nude mice to examine the differences in tumor growth with and without GTE treatment. After the volume of the H23/0.3 xenografted tumor reached approximately $100-200 \mathrm{~mm}^{3}$, the nude mice were treated with either GTE $(100 \mathrm{mg} / \mathrm{kg} /$ day) or vehicle orally (p.o.) for 45 days. As shown in Figure 7(a), the nude mice treated with GTE exhibited a significant suppression in H23/0.3 tumor growth relative to that of the control group. There was no significant difference in the body weights of the mice with and without GTE treatment (data not shown). In addition, as illustrated in Figure 7(b), we found that the numbers of mitotic cancer cells were significantly suppressed by the GTE treatment compared to those of the control group $(85.43 \pm 21.68$ versus $58.71 \pm 12$ in 5 HPFs, $P=0.048)$. These results indicate that GTE suppresses the growth of $\mathrm{H} 23 / 0.3$ xenografted tumors in vivo.

We also evaluated the possibility of a toxic effect of GTE by conducting a pathological examination of all of the sacrificed and dissected mouse organs; the brain, heart, lung, liver, spleen, kidney, and intestines from 7 cases with and 7 cases without GTE treatment were examined. Toxicity was 

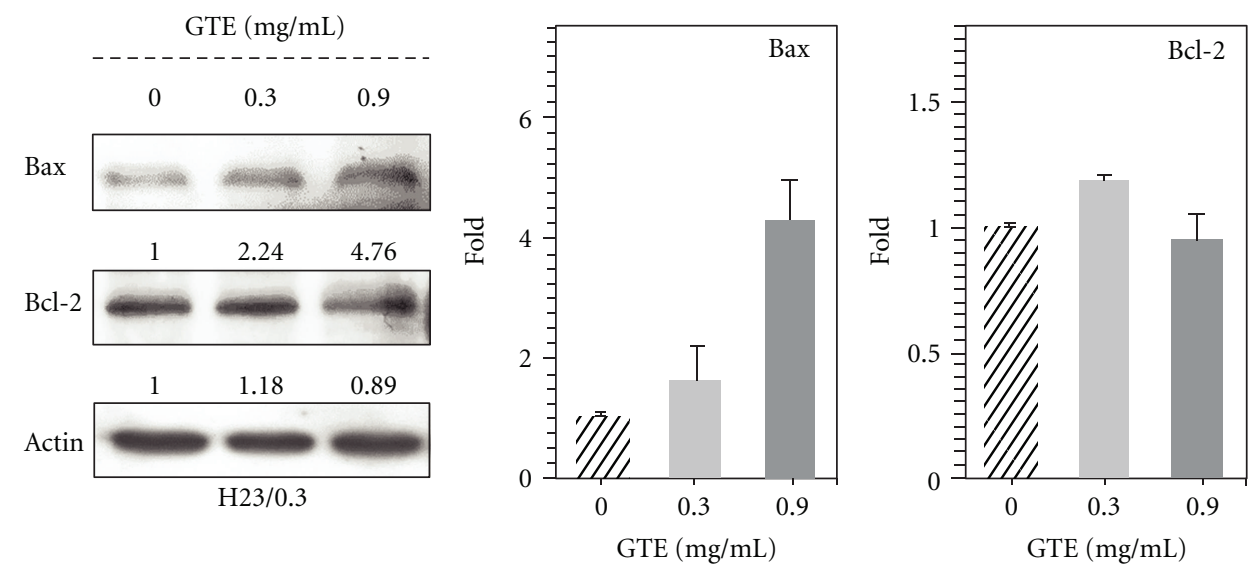

(a)

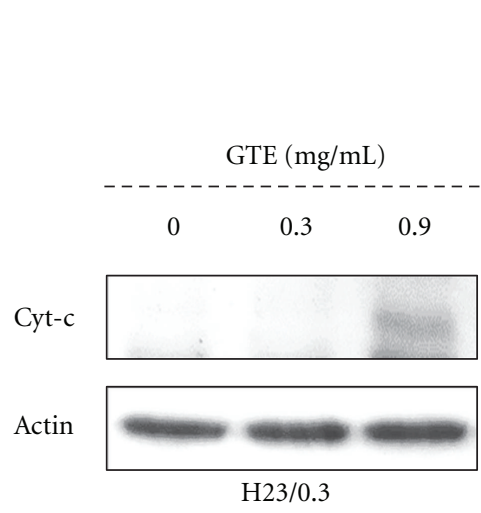

(b)

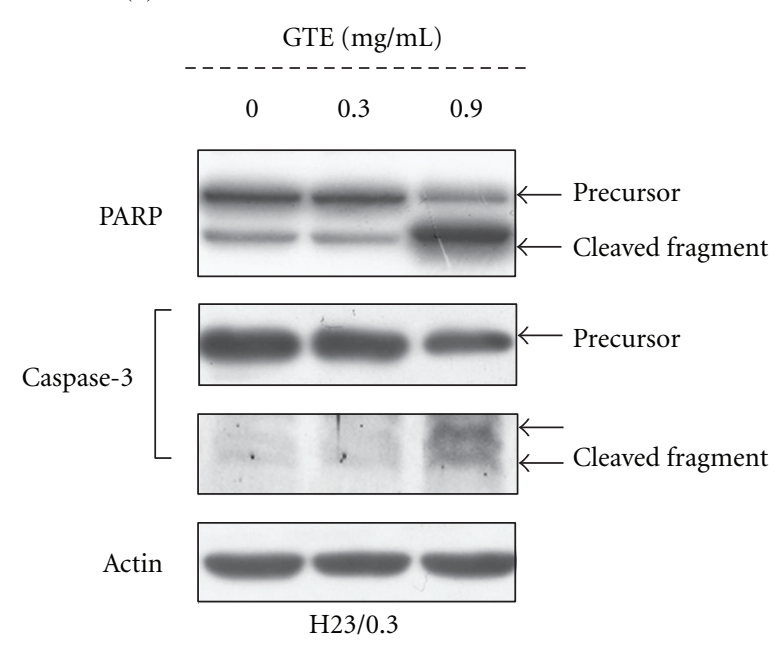

(c)

FIgURE 5: Effect of GTE on the mitochondria/caspase pathway in H23/0.3 cells. (a) H23/0.3 cells were treated with various concentrations of GTE $(0 \mathrm{mg} / \mathrm{mL}, 0.3 \mathrm{mg} / \mathrm{mL}$, and $0.9 \mathrm{mg} / \mathrm{mL})$ for $24 \mathrm{~h}$. The protein expression of Bcl-2 and Bax was measured by western blotting. (b) $\mathrm{H} 23 / 0.3$ cells were treated with various concentrations of GTE $(0 \mathrm{mg} / \mathrm{mL}, 0.3 \mathrm{mg} / \mathrm{mL}$, and $0.9 \mathrm{mg} / \mathrm{mL})$ for $24 \mathrm{~h}$. The release of cytochrome c (Cyt-c) into the cytoplasm was detected by western blotting. (c) H23/0.3 cells were treated with various concentrations of GTE ( $0 \mathrm{mg} / \mathrm{mL}$, $0.3 \mathrm{mg} / \mathrm{mL}$, and $0.9 \mathrm{mg} / \mathrm{mL}$ ) for $24 \mathrm{~h}$. The cleavage of caspase- 3 and PARP was detected by western blotting. Results are expressed as the mean \pm SD of three independent experiments.

evaluated in terms of the severity of hemorrhage, necrosis, and inflammation on microscopic visual scales from "-" to " +++ " that stand for none, mild, moderate, and severe, respectively. There were no significant differences in the aforementioned organ toxicities between the controls and the GTE-treated mice (Table 1).

\section{Discussion}

A number of Chinese herbal medicines have demonstrated significant potential as anticancer therapeutic agents due to their growth suppression effects on tumor cells $[25,26]$. Among these medicines, Ganoderma is the most widely used herbal medicine in Asia and has been used for centuries. Ganoderma tsugae (GT), one of the most major species cultivated in Taiwan, has been shown to exhibit antiproliferative effects against human tumor cells $[12,13]$. In this study, we investigated the anticancer effects of the GT on the NSCLC H23/0.3 cells in vitro (Figure 2(a)) and in vivo (Figure 7(a)).

Botanical products, especially TCMs, are mixtures of phytochemicals that are not defined by the standard formula as pure chemical compounds, thus presenting a difficult issue for the scientific requirements of quality control (QC). Chemical fingerprinting is usually viewed as a gold standard to identify TCMs [27]; however, this method may not be the best method to achieve this core purpose. In comparison with the classification of botanical products by chemical fingerprints, the biological response will be more appropriate in characterizing the therapeutic effects, particularly for those products with mixed compounds, such as TCM [16]. In this study, we used a comprehensive PhytomicsQC platform as a scientific approach for the QC of TCMs (e.g., GTE). Both the bioresponse fingerprint and the chemical 

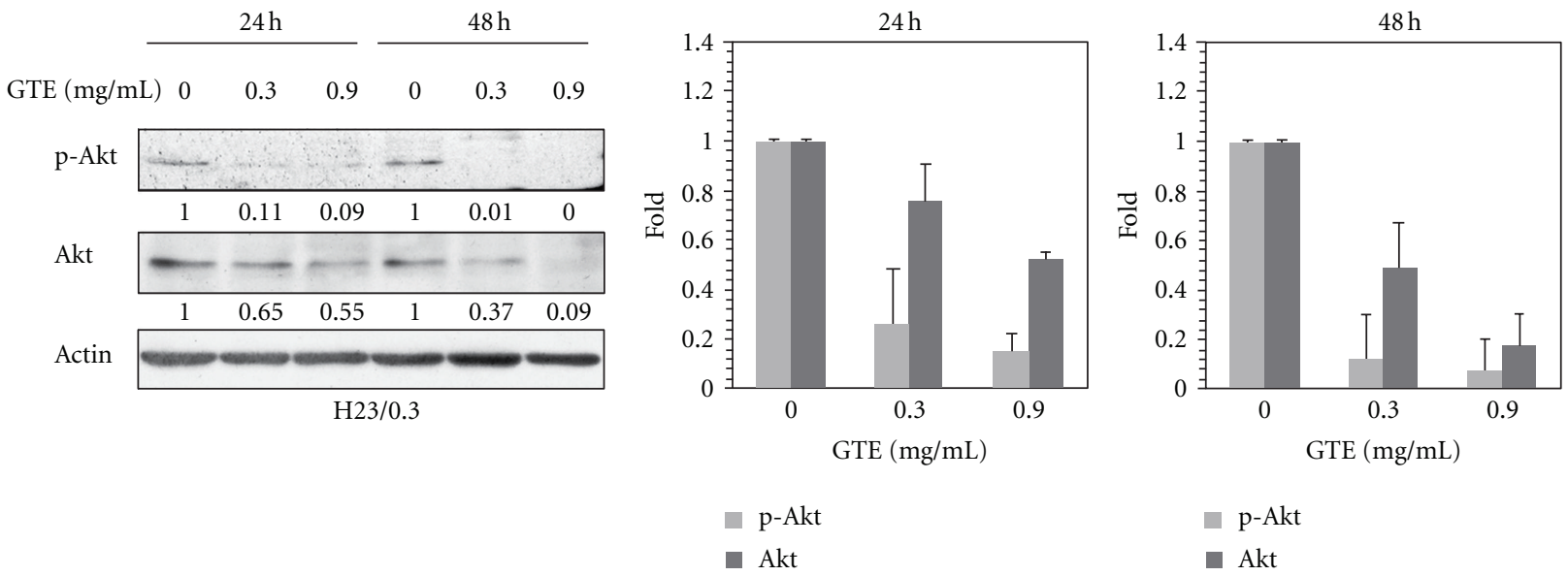

$$
\begin{aligned}
& \text { p-Akt } \\
& \text { - Akt }
\end{aligned}
$$

(a)

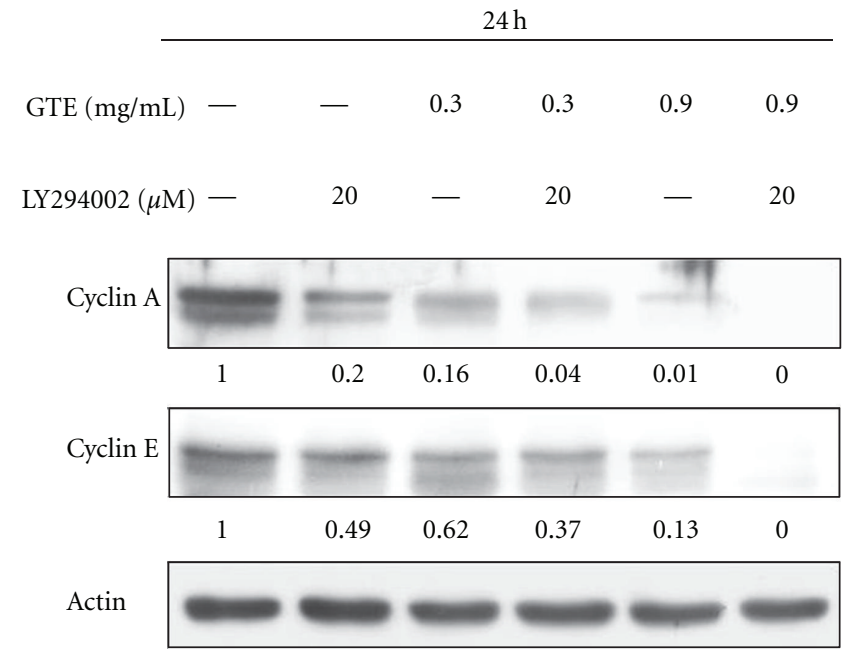

H23/0.3

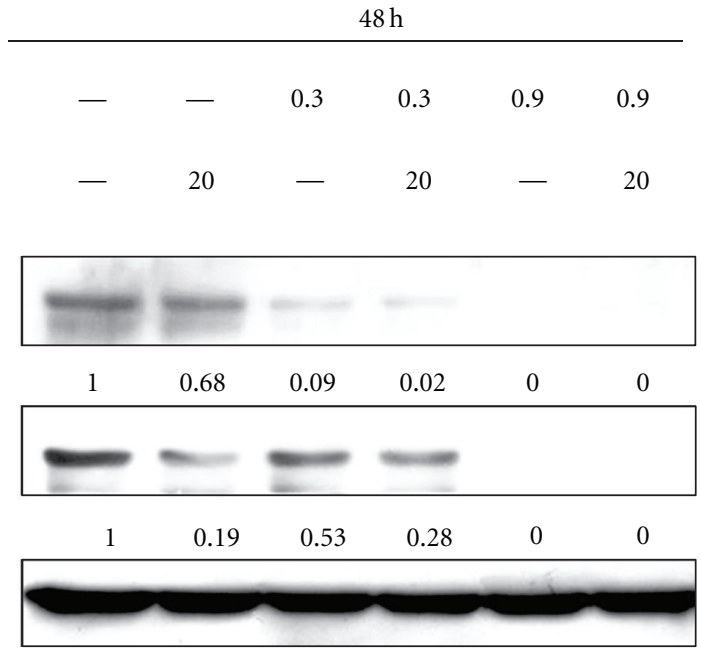

H23/0.3

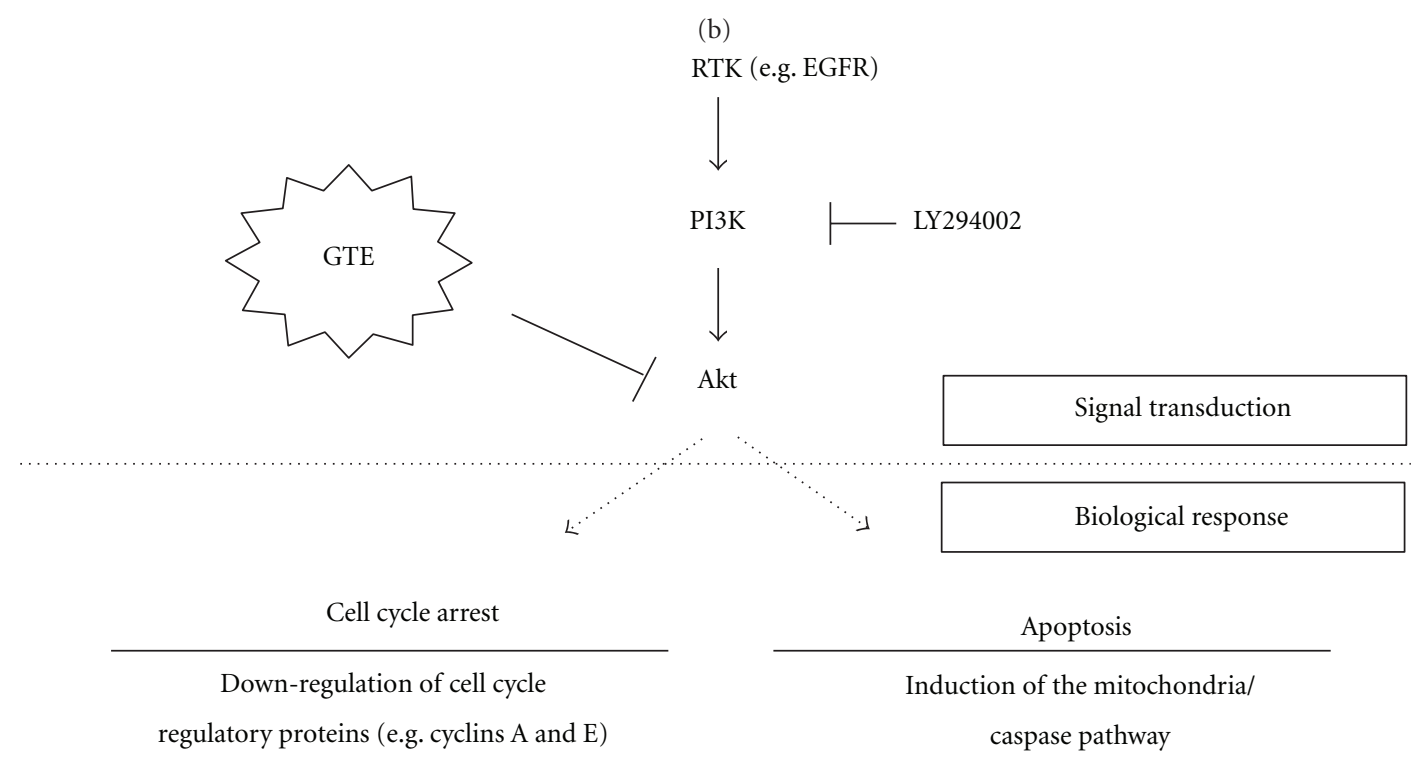

(c)

FIGURE 6: Effect of GTE on PI3K/Akt pathways in H23/0.3 cells. (a) H23/0.3 cells were treated with various concentrations of GTE ( 0 mg/mL, $0.3 \mathrm{mg} / \mathrm{mL}$, and $0.9 \mathrm{mg} / \mathrm{mL}$ ) for $24 \mathrm{~h}$ and $48 \mathrm{~h}$. The protein levels of p-Akt and Akt were measured by western blotting. (b) H23/0.3 cells were treated with $20 \mu \mathrm{M}$ LY294002 (a PI3K inhibitor) alone or in combination with GTE $(0.3 \mathrm{mg} / \mathrm{mL}$ or $0.9 \mathrm{mg} / \mathrm{mL}$ ) for $24 \mathrm{~h}$ and $48 \mathrm{~h}$. The expression levels of proteins (cyclins A and E) were measured by western blotting. (c) A proposed model for the GTE-mediated antiproliferation of doxorubicin-resistant lung adenocarcinoma H23/0.3 cells. Results are expressed as the mean \pm SD of three independent experiments. 


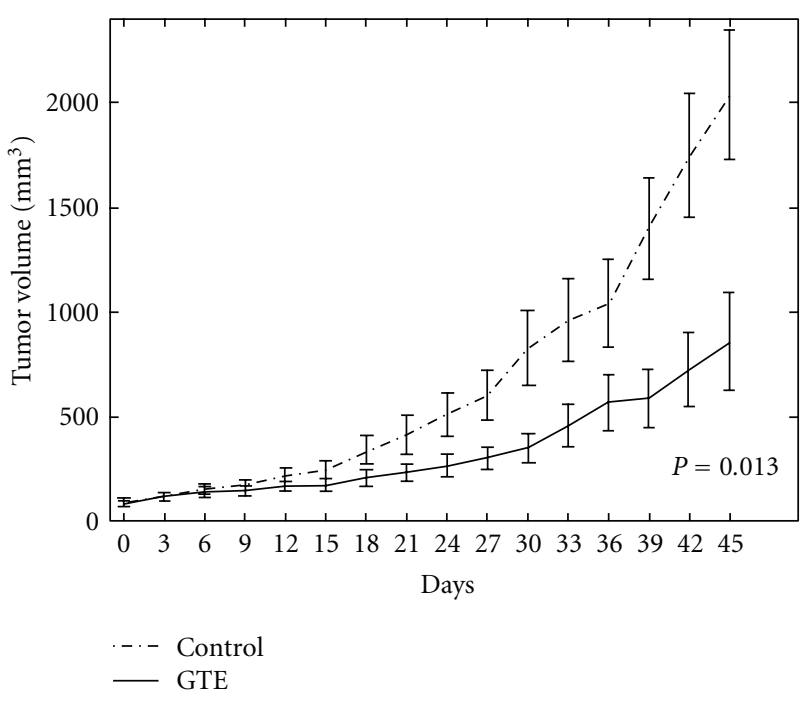

(a)

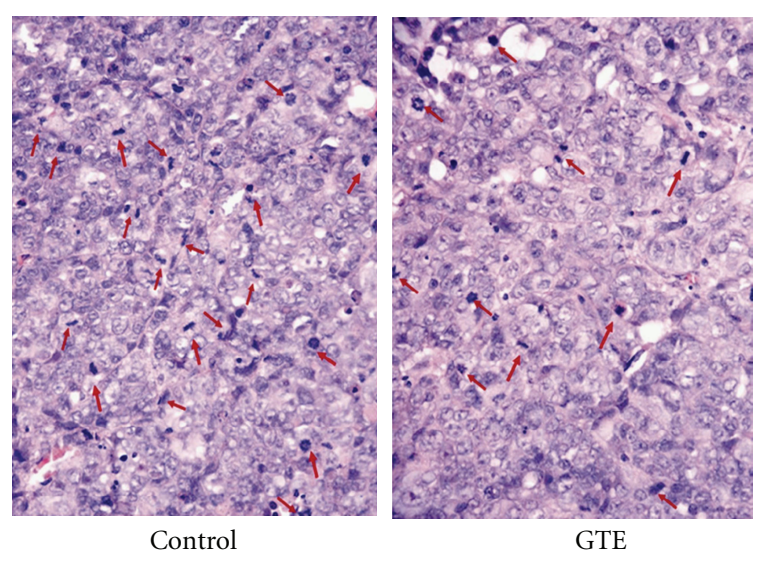

(b)

FIGURE 7: Effect of GTE on the growth of H23/0.3 xenografted tumors in vivo. (a) The tumor growth rate was significantly retarded in the GTE-treated group $(100 \mathrm{mg} / \mathrm{kg} /$ day $)$. The tumor volumes were estimated from the caliper measurements of three dimensions of the tumor. The estimated tumor volumes were calculated as $L \times W^{2} \times 0.5$, where $L$ is the major axis and $W$ is tumor width. The data are represented as the mean \pm SE $(n=10)$. (b) The tumor sections from the control mice showed more mitotic cells compared to those from the GTE-treated mice. The red arrows indicate mitotic figures in the H\&E-stained areas (400X).

fingerprint [16] of GTEs were determined and revealed the high quality and consistency among different batches of GTE (Figures 1(a)-1(c)).

Perturbation of progression of the cell cycle in tumor cells is a helpful strategy to halt tumor growth [21]. Furthermore, the cell cycle arrest of tumor cells also provides an occasion for cells to undergo either repair or cellular apoptosis. A number of TCMs exhibit significant inhibitory effects on lung cancer cells via disruption of cell cycle progression and/or induction of cell apoptosis $[25,26]$. Previous reports showed that a G2/M cell cycle arrest was induced in Hep3B cells treated with the chloroform extract of GT [9] and in COLO 205 cells exposed to the methanol extract of GT [10]. In this study, our in vitro data indicated that the treatment of $\mathrm{H} 23 / 0.3$ cells with ethanol extract of GT induced S phase arrest (Figure 3(a)) via modulation of the expression of $S$ phase regulatory proteins (Figures $3(\mathrm{~b})$ and $3(\mathrm{c})$ ) in $\mathrm{H} 23 / 0.3$ cells. The various effects of GT on the distribution of cell cycle may be due to cell-type specificity and/or result from variations in preparation process of GT extract.

Many anticancer drugs/agents exert their anticancer activities by inducing the cellular apoptosis of tumor cells [28]. Resistance to cellular apoptosis, therefore, results in a decrease in the sensitivity of cancer cells to drugs and the failure of chemotherapy $[22,29]$. Several TCMs have been reported to induce cellular apoptosis in lung cancer $[25,26]$. For example, Typhonium blumei extract induces cellular apoptosis via the mitochondrial/caspase pathway by upregulating the expression of proapoptotic proteins (e.g., Bax, Bad, and Bak), downregulating the expression of antiapoptotic proteins (e.g., Bcl-2 and $\mathrm{Bcl}-\mathrm{xL}$ ), and activating caspase-9 and caspase-3 in lung cancer A549 cells [26], whereas Scutellaria baicalensis extract induces apoptosis by upregulating the expression of the proteins p53 and Bax in lung cancer A549 cells [25]. In this study, our results indicated that GTE not only perturbed cell cycle progression but also induced cellular apoptosis in lung cancer H23/0.3 cells (Figures 4(a)-4(c)). Furthermore, we also found that the treatment of $\mathrm{H} 23 / 0.3$ cells with GTE resulted in a marked increase in the expression of Bax (Figure 5(a)). This increase may be responsible for the concomitant execution phase of cellular apoptosis such as an increase in the release of Cyt-c from the mitochondria to the cytosol and the activation/cleavage of caspase-3 and PARP (Figure 5(c)).

The PI3K/Akt signaling pathway plays a critical role in cell proliferation, survival, and drug resistance in lung cancer [24]. Therefore, the suppression of the PI3K/Akt signaling pathway may be an effective approach to the treatment of lung cancer $[30,31]$. In this study, we found that GTE inhibits the protein levels of Akt and phospho-Akt in H23/0.3 cells (Figure 6(a)). The inhibitory influence of GTE on phospho-Akt levels may be governed by its ability to suppress the expression of the Akt protein. We incubated H23/0.3 cells with LY294002, a PI3K-specific inhibitor, to confirm that GTE inhibits the proliferation of lung cancer H23/0.3 cells via modulation of the PI3K/Akt signaling pathway (Figure 6(b)). These results suggest that GTE may be a useful Akt-targeting agent for the treatment of lung cancer.

A number of reports show that the combined usage of some extracts from herbs (such as coptis rhizoma and glycyrrhizae radix) with anticancer agents results in a synergistic growth inhibitory effect on cancer cells [32, 33]. It has also been reported that a combination of Ganoderma with anticancer agents significantly slows the growth rate of cancer cells [13, 34]. For example, the combined treatment of taxol with Ganoderma tsugae (GT) extract results in a 
synergistic growth suppression effect on colorectal cancer COLO205 cells [13], and Ganoderma lucidum enhances the chemotherapeutic efficacy of doxorubicin against SCLC H69 and VPA cells (a multidrug resistant cell line derived from H69 cells) [34]. Similarly, we demonstrated that a combination of doxorubicin with GTE resulted in a marked reduction in the number of viable NSCLC H23/0.3 cells (Figure 2(c)). These results suggest that GTE may be a promising adjuvant to anticancer agents in the treatment of drug resistant NSCLC cells.

In conclusion, we have demonstrated that GTE induces $S$ phase arrest and the cellular apoptosis of $\mathrm{H} 23 / 0.3$ cells via regulation of the PI3K/Akt signaling pathways (Figure 6(c)). In addition, we have also shown that a combination of GTE and doxorubicin exerts an enhanced growth inhibitory effect on $\mathrm{H} 23 / 0.3$ cells. Our results suggest that GTE may be a safe and effective adjuvant therapeutic agent for the treatment of NSCLC cells with drug resistance.

\section{Acknowledgments}

The authors are grateful to Mr. Fon-Chang Liu for his technical assistance in conducting chromatography. This work was supported by grants from the National Science Council (NSC99-2320-B-039-023, and NSC100-2313-B-039-005MY3) and Department of Health Clinical Trial and Research Center of Excellence (DOH101-TD-C-111-005), and China Medical University (Taichung) (CMU99-NTU-11), Taiwan, Republic of China. We also wish to thank members of the Medical Research Core Facilities Center (Office of Research \& Development, China Medical University, Taichung, Taiwan) for their excellent technical support. H.-P. Kuo, H.-H Hsieh are contributed equally to this study.

\section{References}

[1] R. Siegel, E. Ward, O. Brawley, and A. Jemal, "Cancer statistics, 2011: the impact of eliminating socioeconomic and racial disparities on premature cancer deaths," CA Cancer Journal for Clinicians, vol. 61, no. 4, pp. 212-236, 2011.

[2] E. Y. Department of Health, Taiwan, "Health and vital statistics," 2011, http://www.doh.gov.tw.

[3] R. S. Herbst, J. V. Heymach, and S. M. Lippman, "Molecular origins of cancer: lung cancer," New England Journal of Medicine, vol. 359, no. 13, pp. 1367-1380, 2008.

[4] D. J. Stewart, "Tumor and host factors that may limit efficacy of chemotherapy in non-small cell and small cell lung cancer," Critical Reviews in Oncology/Hematology, vol. 75, no. 3, pp. 173-234, 2010.

[5] X. Zhou, J. Lin, Y. Yin, J. Zhao, X. Sun, and K. Tang, "Ganoderma taceae: natural products and their related pharmacological functions," American Journal of Chinese Medicine, vol. 35, no. 4, pp. 559-574, 2007.

[6] H. H. Ko, C. F. Hung, J. P. Wang, and C. N. Lin, "Antiinflammatory triterpenoids and steroids from Ganoderma lucidum and G. tsugae," Phytochemistry, vol. 69, no. 1, pp. 234-239, 2008.

[7] Y. W. Wu, K. D. Chen, and W. C. Lin, "Effect of Ganoderma tsugae on chronically carbon tetrachloride-intoxicated rats,"
American Journal of Chinese Medicine, vol. 32, no. 6, pp. 841$850,2004$.

[8] N. S. Lai, R. H. Lin, R. S. Lai, U. C. Kun, and S. C. Leu, "Prevention of autoantibody formation and prolonged survival in New Zealand Black/New Zealand White F1 mice with an ancient Chinese herb, Ganoderma tsugae," Lupus, vol. 10, no. 7, pp. 461-465, 2001.

[9] J. L. Mau, H. C. Lin, and C. C. Chen, "Antioxidant properties of several medicinal mushrooms," Journal of Agricultural and Food Chemistry, vol. 50, no. 21, pp. 6072-6077, 2002.

[10] G. Wang, J. Zhang, T. Mizuno et al., "Antitumor active polysaccharides from the Chinese mushroom Songshan lingzhi, the fruiting body of Ganoderma tsugae," Bioscience, biotechnology, and biochemistry, vol. 57, no. 6, pp. 894-900, 1993.

[11] G. G. L. Yue, K. P. Fung, G. M. K. Tse, P. C. Leung, and C. B. S. Lau, "Comparative studies of various Ganoderma species and their different parts with regard to their antitumor and immunomodulating activities in vitro," Journal of Alternative and Complementary Medicine, vol. 12, no. 8, pp. 777-789, 2006.

[12] K. H. Gan, Y. F. Fann, S. H. Hsu, K. W. Kuo, and C. N. Lin, "Mediation of the cytotoxicity of lanostanoids and steroids of Ganoderma tsugae through apoptosis and cell cycle," Journal of Natural Products, vol. 61, no. 4, pp. 485-487, 1998.

[13] S. C. Hsu, C. C. Ou, J. W. Li et al., "Ganoderma tsugae extracts inhibit colorectal cancer cell growth via G2/M cell cycle arrest," Journal of Ethnopharmacology, vol. 120, no. 3, pp. 394-401, 2008.

[14] S. C. Hsu, C. C. Ou, T. C. Chuang et al., "Ganoderma tsugae extract inhibits expression of epidermal growth factor receptor and angiogenesis in human epidermoid carcinoma cells: in vitro and in vivo," Cancer Letters, vol. 281, no. 1, pp. 108-116, 2009.

[15] B. Boh, M. Berovic, J. Zhang, and L. Zhi-Bin, "Ganoderma lucidum and its pharmaceutically active compounds," Biotechnology Annual Review, vol. 13, pp. 265-301, 2007.

[16] R. Tilton, A. A. Paiva, J. Q. Guan et al., "A comprehensive platform for quality control of botanical drugs (PhytomicsQC): a case study of Huangqin Tang (HQT) and PHY906," Chinese Medicine, vol. 5, article no. 30, 2010.

[17] H. P. Kuo, T. C. Chuang, M. H. Yeh et al., "Growth suppression of HER2-overexpressing breast cancer cells by berberine via modulation of the HER2/PI3K/Akt signaling pathway," Journal of Agricultural and Food Chemistry, vol. 59, no. 15, pp. 8216-8224, 2011.

[18] M. H. Hsu, C. J. Chen, S. C. Kuo et al., "2-(3-Fluorophenyl)6-methoxyl-4-oxo-1,4-dihydroquinoline-3-carboxylic acid (YJC-1) induces mitotic phase arrest in A549 cells," European Journal of Pharmacology, vol. 559, no. 1, pp. 14-20, 2007.

[19] K. Nishio, T. Nakamura, Y. Koh, T. Suzuki, H. Fukumoto, and N. Saijo, "Drug resistance in lung cancer," Current Opinion in Oncology, vol. 11, no. 2, pp. 109-115, 1999.

[20] R. Boutros, V. Lobjois, and B. Ducommun, "CDC25 phosphatases in cancer cells: key players? Good targets?" Nature Reviews Cancer, vol. 7, no. 7, pp. 495-507, 2007.

[21] K. Collins, T. Jacks, and N. P. Pavletich, "The cell cycle and cancer," Proceedings of the National Academy of Sciences of the United States of America, vol. 94, no. 7, pp. 2776-2778, 1997.

[22] F. H. Igney and P. H. Krammer, "Death and anti-death: tumour resistance to apoptosis," Nature Reviews Cancer, vol. 2, no. 4, pp. 277-288, 2002. 
[23] S. Cory and J. M. Adams, "The BCL2 family: regulators of the cellular life-or-death switch," Nature Reviews Cancer, vol. 2, no. 9, pp. 647-656, 2002.

[24] C. X. Xu, H. Jin, J. Y. Shin, J. E. Kim, and M. H. Cho, "Roles of protein kinase B/Akt in lung cancer," Frontiers in Bioscience, vol. 2, pp. 1472-1484, 2010.

[25] J. Gao, W. A. Morgan, A. Sanchez-Medina, and O. Corcoran, "The ethanol extract of Scutellaria baicalensis and the active compounds induce cell cycle arrest and apoptosis including upregulation of p53 and Bax in human lung cancer cells," Toxicology and Applied Pharmacology, vol. 254, no. 3, pp. 221$228,2011$.

[26] H. F. Hsu, K. H. Huang, K. J. Lu et al., "Typhonium blumei extract inhibits proliferation of human lung adenocarcinoma A549 cells via induction of cell cycle arrest and apoptosis," Journal of Ethnopharmacology, vol. 135, no. 2, pp. 492-500, 2011.

[27] S. Li, Q. Han, C. Qiao, J. Song, C. L. Cheng, and H. Xu, "Chemical markers for the quality control of herbal medicines: an overview," Chinese Medicine, vol. 3, article no. 7, 2008.

[28] T. Ohmori, E. R. Podack, K. Nishio et al., "Apoptosis of lung cancer cells caused by some anti-cancer agents (MMC, CPT11, ADM) is inhibited by BCL-2," Biochemical and Biophysical Research Communications, vol. 192, no. 1, pp. 30-36, 1993.

[29] R. J. Arceci, "Mechanisms of resistance to therapy and tumor cell survival," Current opinion in hematology, vol. 2, no. 4, pp. 268-274, 1995.

[30] S. C. Park, H. S. Yoo, C. Park et al., "Induction of apoptosis in human lung carcinoma cells by the water extract of Panax notoginseng is associated with the activation of caspase3 through downregulation of Akt," International Journal of Oncology, vol. 35, no. 1, pp. 121-127, 2009.

[31] E. Nam and C. Park, "Maspin suppresses survival of lung cancer cells through modulation of Akt pathway," Cancer Research and Treatment, vol. 42, no. 1, pp. 42-47, 2010.

[32] J. Liu, C. He, K. Zhou, J. Wang, and J. X. Kang, "Coptis extracts enhance the anticancer effect of estrogen receptor antagonists on human breast cancer cells," Biochemical and Biophysical Research Communications, vol. 378, no. 2, pp. 174-178, 2009.

[33] K. Takara, S. Horibe, Y. Obata, E. Yoshikawa, N. Ohnishi, and T. Yokoyama, "Effects of 19 herbal extracts on the sensitivity to paclitaxel or 5-fluorouracil in HeLa cells," Biological and Pharmaceutical Bulletin, vol. 28, no. 1, pp. 138-142, 2005.

[34] D. Sadava, D. W. Still, R. R. Mudry, and S. E. Kane, "Effect of Ganoderma on drug-sensitive and multidrug-resistant smallcell lung carcinoma cells," Cancer Letters, vol. 277, no. 2, pp. 182-189, 2009. 


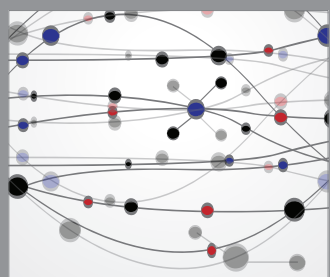

The Scientific World Journal
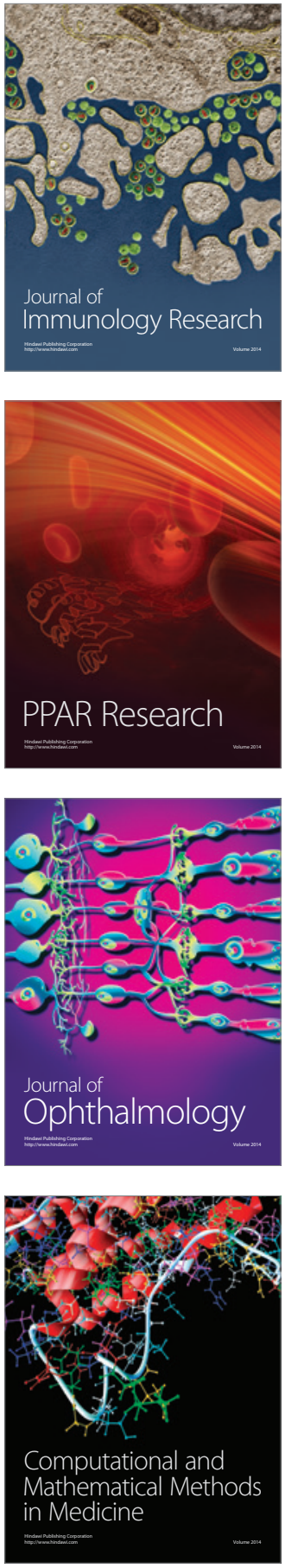

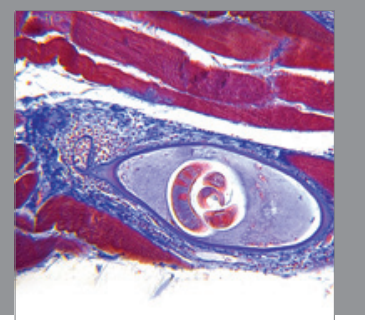

Gastroenterology

Research and Practice
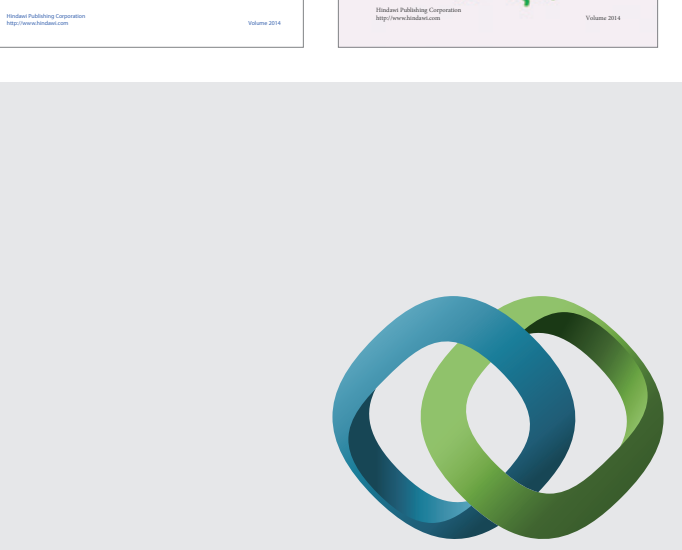

\section{Hindawi}

Submit your manuscripts at

http://www.hindawi.com
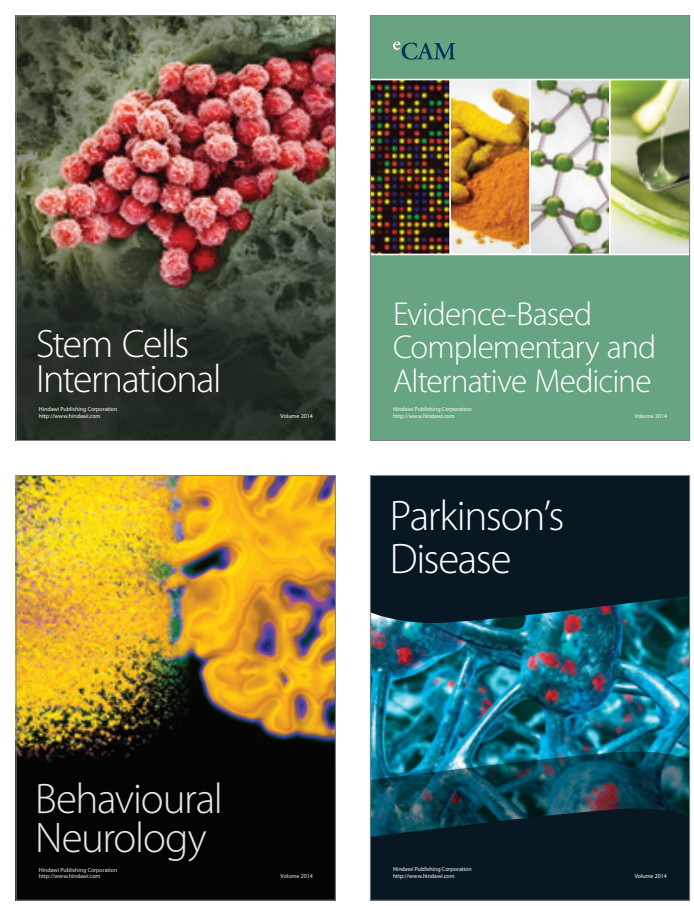

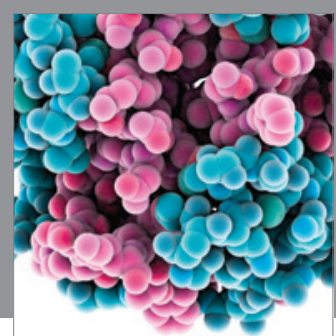

Journal of
Diabetes Research

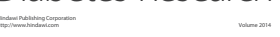

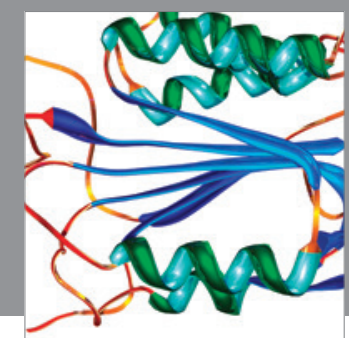

Disease Markers
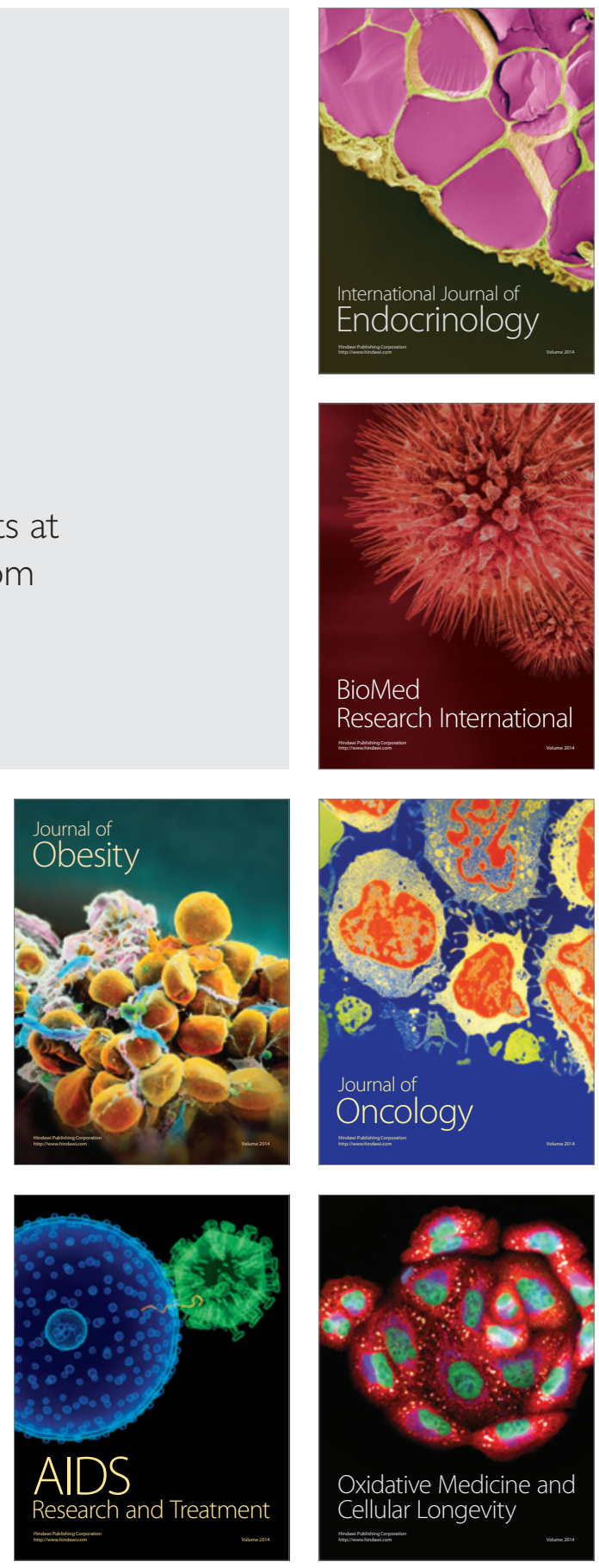